\title{
Thermal and electrochemical studies of Fe(III) organophilic montmorillonite
}

\author{
Bruno Trevizan Franzin ${ }^{1} \cdot$ Caroline Polini Lupi $^{1} \cdot$ Lucas Alves Martins $^{1} \cdot$ \\ Filipe Corrêa Guizellini' ${ }^{2}$ Cecília Cristina Marques dos Santos ${ }^{1,3}$. \\ Iêda Aparecida Pastre ${ }^{1}$. Fernando Luis Fertonani ${ }^{1}$
}

Received: 12 June 2016/ Accepted: 18 March 2017/Published online: 3 April 2017

(C) Akadémiai Kiadó, Budapest, Hungary 2017

\begin{abstract}
This study aimed at investigating the thermal and electrochemical behavior of montmorillonite clay-8hydroxyquinoline (8-HQ) film in the absence and presence of aqueous Fe(III) ions. The solid film characterization by means of UV spectroscopy, thermal (TG/DTG and TGDTA, simultaneous) studies, SEM and optical images, and XRD suggested the formation of the ternary complex type: $\left\{\mathrm{Pt} /[>\mathrm{Si}-\mathrm{O}]_{\mathrm{n}}\left[\mathrm{Fe}(\mathrm{III})\left(\mathrm{OH}_{2}\right)_{3}(8-\mathrm{HQ})_{\mathrm{k}}\right]\right\}^{3-\mathrm{n}-\mathrm{k}}$, with thermal stability up to $300{ }^{\circ} \mathrm{C}$. The electrochemical study was carried out on a platinum electrode modified by mechanical deposition of a thin solid film of the binary composite (SWy-1:8-HQ) from an aqueous suspension. The mechanical stability of the film was followed by performing 80 cyclic voltammograms. The electrochemical behavior of the modified electrode was investigated using cyclic voltammetry $(\mathrm{CV})$ at different ferric ions concentration $\left.\left(C_{\mathrm{Fe}(\mathrm{III}}\right)\right)$, followed by a study of the effect of the scan rate $(v)$ with a fixed $C_{\mathrm{Fe}(\mathrm{III})}$ ions. In the $\mathrm{CVs}$, two independent pairs of current peaks, $\mathrm{A} / \mathrm{D}$ and $\mathrm{C} / \mathrm{B}$, were observed. For $\mathrm{Fe}$ (III) ions in solution, $\log i_{\mathrm{p}}$ versus $\log$ $v$ relationship shows a process controlled first by adsorption (pair of peaks $\mathrm{A} / \mathrm{D}$ ) and then by diffusion control (pair of peaks C/B). The current function $i_{\mathrm{p}} / v^{1 / 2}$ versus $v$ and $i_{\mathrm{p}}^{\mathrm{a}} / i_{\mathrm{p}}^{\mathrm{c}}$ versus $v$ allowed a suggestion of two homogeneous coupled chemical reactions associated with $\mathrm{CE}$ and EC mechanisms, respectively, both with fast reversible chemical
\end{abstract}

Fernando Luis Fertonani

fertonan@ibilce.unesp.br

1 Departamento de Química e Ciências Ambientais, IBILCE/ Unesp, S. J. Rio Preto, SP, Brazil

2 Departamento de Química, Universidade Estadual de Londrina - UEL, Londrina, PR, Brazil

3 Instituto Adolfo Lutz, São José do Rio Preto, SP, Brazil reactions. The first investigation of a modified electrode showed good sensitivity $\left(S=25.1 \mu \mathrm{A} / \mu \mathrm{mol} \mathrm{L}{ }^{-1}\right)$ to low concentrations of ferric ions and detection limit $\left[\mathrm{LOD}=(2.4 \pm 0.01) \mu \mathrm{mol} \mathrm{L}{ }^{-1}\right]$ and high sensitivity to traces of $\mathrm{O}_{2}$, showing that this system has great analytical potentials.

Keywords Organic montmorillonite - Electrochemistry · Determination of $\mathrm{Fe}(\mathrm{III})$ ions $\cdot$ Pt-modified electrode $\cdot \mathrm{TG}-$ DTA $\cdot$ XRD

\section{Introduction}

The generation of large quantities of effluents with high levels of undesirable organic compounds and toxic metal ions is the result of several human activities. Among these activities is the increased use of these compounds in different industrial processes and products by setting up a legal and vital action for the removal and control of the concentration of these ions in various matrices. The presence of metal ions (i.e.: $\mathrm{Cu}(\mathrm{II}), \mathrm{Cd}(\mathrm{II}), \mathrm{Pb}(\mathrm{II}), \mathrm{Zn}(\mathrm{II})$, among others and organoleptic $\mathrm{Fe}(\mathrm{III})$ and $\mathrm{Al}(\mathrm{III})$, ions), particularly in the environment, is responsible for the contamination of drinking water sources and the organisms living in this medium, representing a range of deleterious effects to fauna, flora, and exposed human beings. However, even considering as toxic, metal ions are essential to human life.

The iron ion plays a key role in living organisms; it is used for oxygen transportation, for DNA synthesis and energetic metabolism [1]. Its lack causes serious health problems anemia being the most well known. However, an excess is also harmful, since it increases the synthesis of reactive oxygen species in cellular tissues, causing lesions 
in the proteins, lipids, and DNA [1, 2]. Another harmful aspect of the presence of iron is the possibility of causing problems for the public water supply. When the iron ion is present in a high concentration, it has organoleptic characteristics such as a bitter taste and is yellow color and blurred, causing stains on clothes and sanitary utensils. The development of deposits of iron in plumbing and the overgrowth of bacteria cause biological contamination of the water distribution network. For these reasons, the iron ion constitutes one of the legislated portability parameters [3].

The iron ion can be found in the environment as, for example, in inorganic species of $\mathrm{Fe}(\mathrm{II})$ or $\mathrm{Fe}(\mathrm{III})$, as organic complexes, in the form of oxyhydroxides in sediments and colloidal oxide $[4,5]$.

Several analytical methods have been used to determinate iron, such as spectrofluorimetric [6, 7], spectrophotometric $[8,9]$, atomic absorption spectrophotometer with flame ionization [10], coupled plasma (ICP-OES) [11], and electrothermal [12]. Accordingly, studies [13-17] have suggested a simple and affordable method that can be used for the determination of trace amounts of $\mathrm{Fe}$ (III) ions in solution by an electrochemical method. Several studies have shown the application of modified electrodes for metal ions determination in aqueous solutions, some of them using a modification process with clays and organoclays [18-25].

Mineralogical clay materials have important characteristics that facilitate its use as an alternative from the economic and environmental viewpoint (low cost, abundance, easy recovering to reuse, etc), coherent with the current reality. These characteristics combined with the high surface area and swelling capacity of smectite clays, used in the present work, encourage significant investment in research in order to enhance the applications conferred to these materials. The use of an expansive 2:1 montmorillonite clay (smectite class) in association with organic molecules, such as 8-hydroxyquinoline (8-HQ) [26-28], increases the stability of the new composite and improves its adsorption capacity of inorganic ions $\left(\mathrm{M}^{\mathrm{n}+}\right)[29,30]$.

The occurrence of clays in the environment, their interactions with natural organic substances, and the retention of ionic species of different metallic ions (toxic or not) on clay or its natural binary complexes are abundant in nature. Recently, our team has been investigating microstructured systems: binary, SWy-1-8-Hydroxyquinoline, and ternaries SWy-1-8-hydroxyquinoline- $\mathrm{M}^{\mathrm{n}+}$ $\left(\mathrm{M}^{\mathrm{n}+}=\mathrm{Cr}\right.$ to $\mathrm{Zn}, \mathrm{Ag}, \mathrm{Cd}, \mathrm{Pb}$, and $\left.\mathrm{Hg}\right)$. These systems have been studied using different spectral (UV-visible and visible fluorescence), thermal, electrochemical, and surface (SEM, XRD, and optical images) techniques to characterize them.

The studies, globally, aim to: 1) find out about the special complexing capacity of 8-hydroxyquinoline, adsorbed by the composite, against most elements of the periodic table and 2) explore its physicochemical properties (complexation and acid-base), for the removal of toxic and organoleptic metallic ions from the water used in urban water supply and wastewater.

In this sense, the investigation of the electrochemical properties of the ternary complexes becomes interesting because it allows the elaboration of a physical system of electrodes that makes possible: 1) the selective removal of the metallic ions, using the physical-chemical and electrochemical properties of ternary complexes and 2) the recovery of the binary system for its reuse.

Thus, the main objective of this paper is to study: 1) the behavior of the montmorillonite-8-hydroxyquinoline composite (SWy-1:8-HQ) in the presence and the absence of the organoleptic Fe(III) ions, by thermal, spectroscopic, SEM, XRD, optical microscopy, and electrochemical techniques, and 2) the elucidation of the global electrochemistry mechanism of SWy-1:Fe(III)8-HQ ternary composite. Also, the aim is to demonstrate: (1) the ease and speed of the preparation of electrodes (repeatability); (2) the speed of the experimental work development; (3) its mechanical and thermal stability that allow its reuse; and (4) its low cost, in relation to the chemicals compounds used (clay and 8HQ) and its reuse. These features make possible future applications of the compound of montmorillonite-8-hydroxyquinoline $(S W y-1: 8-H Q)$ not just for global mechanism studies but to future quantitative determination of electrochemical $\mathrm{Fe}$ (III) ions and indirect determination of trace amounts of oxygen, and also as adsorbents for wastewater and urban water purification process.

\section{Experimental}

\section{Preparation of SWy-1 suspension}

Montmorillonite SWy-1 (homoionic clay, Na-montmorillonite) from Wyoming, USA, provided by the Clay Minerals Society, Source Clays Repository (Purdue University, USA), was used in the studies. For electrochemical and spectroscopic studies, an aqueous suspension of $0.11 \mathrm{~g} \mathrm{~L}^{-1}$ montmorillonite (SWy-1) was prepared by dispersion of appropriated mass of SWy-1 in deionized water and maintained under mechanical stirring for another $24 \mathrm{~h}$.

\section{Preparation of the SWy-1:8-HQ and SWy-1:8-HQ- Fe(III) composites}

For electrochemical and spectroscopic studies, an aqueous suspension of SWy-1 was previously prepared and pure solid 8-hydroxyquinoline (8-HQ) was added in a proportion of $10 \%$ mass and maintained under mechanical stirring for 
$24 \mathrm{~h}$, generating the binary composite, SWy-1:8-HQ. For the studies in solid state, a methanolic suspension of SWy1:8-HQ was likewise prepared for the aqueous suspension described above. In one portion of suspension of SWy-1:8$\mathrm{HQ}, \mathrm{Fe}(\mathrm{III})$ ions were added from a stock solution of $\mathrm{Fe}\left(\mathrm{NO}_{3}\right) \cdot 9 \mathrm{H}_{2} \mathrm{O}$ with a concentration $5.38 \times 10^{-2} \mathrm{~mol} \mathrm{~L}^{-1}$ and maintained under mechanical stirring for another $24 \mathrm{~h}$, generating the ternary composite, SWy-1:8-HQ-Fe(III). Then, the resulting suspensions were dried under a laboratory fume exhaust hood for $24 \mathrm{~h}$, producing the solid binary and ternary composites. Thermal analysis (TG/DTG and TG-DTA), XRD, SEM, and optical images were performed on these samples.

\section{Electrode surface modification}

The suspension SWy-1:8-HQ prepared as described in the previous item was re-suspended by stirring it for $12 \mathrm{~h}$. To prepare the SWy-1:8-HQ film electrode: SWy-1:8-HQ suspension increments of $0.5 \mu \mathrm{L}$ were applied on the top of the platinum disk in order to cover the entire surface with a single drop. The solvent was evaporated in a forced circulation air stove at $50{ }^{\circ} \mathrm{C}$ for $20 \mathrm{~min}$. The procedure was repeated five times to obtain a suitable film thickness.

\section{Study of the electrochemical behavior of SWy-1:8- HQ composite film}

Cyclic voltammetric experiments were performed by applying the following potential program: $E_{\text {start }}=$ $E_{\text {end }}=-0.7 \mathrm{~V}$ and $E_{\text {inv. }}=+0.5 \mathrm{~V}$, scan rate $(25 \leq v \leq 200) \mathrm{mV} \mathrm{s}^{-1}$ using $0.1 \mathrm{~mol} \mathrm{~L}^{-1} \mathrm{KCl}$ as supporting electrolyte, deaerated with $\mathrm{N}_{2}$, in the absence and presence of $2.40 \times 10^{-6} \mathrm{~mol} \mathrm{~L}^{-1}$ of Fe(III) ions. Cyclic voltammograms were obtained in a Microquímica potentiostat model MPQG-01. A three-electrode electrochemical cell of $10 \mathrm{~mL}$ was used for the CVs measurements: a $\mathrm{Pt}$ working electrode with geometric area, $A_{\text {geom }}=0.0314 \mathrm{~cm}^{2}$, modified with SWy-1:8-HQ composite; a reference electrode $\mathrm{Ag}|\mathrm{AgCl}| \mathrm{KNO}_{3 \text { (sat.) }}(E=0.465 \mathrm{~V} / \mathrm{ERH})$; and an Ir foil as counter electrode $\left(A_{\text {geom. }}=1.025 \mathrm{~cm}^{2}\right)$.

\section{Study of the spectrophotometric behavior (UV) of the composites}

UV-Vis spectra of the SWy-1:8-HQ suspensions were obtained in the absence and presence of different concentrations of $\mathrm{Fe}(\mathrm{III})$ ions $\left(0.1<C_{\mathrm{Fe}(\mathrm{III})}<1.61\right) \times 10^{-5}$ $\mathrm{mol} \mathrm{L}^{-1}$ in order to study the possible formation of complex species, such as Fe(III)-8-HQ adsorbed into the SWy-1, originating the named ternary composite (SWy-1:Fe(III)-8HQ) and their effect on the spectra, using an UV-Vis
Cary $1 \mathrm{E}$ (Varian) and a quartz cell with $1.00 \mathrm{~cm}$ of optical path.

\section{Thermal characterization and $\mathrm{X}$-ray diffraction of composites}

The thermal study of composite SWy-1:8-HQ-Fe(III) was made for samples prepared in the previous item (preparation of the SWy-1:8-HQ and SWy-1:8-HQ-Fe(III) composites) employing a sample mass of $7 \mathrm{mg}$. The mass samples were subjected to a heating rate of $\beta=20^{\circ} \mathrm{C} \mathrm{min}^{-1}$ in an air and/or nitrogen $\left(\mathrm{N}_{2}\right)$ dynamic atmosphere, with a flow rate of $50 \mathrm{~mL} \min ^{-1}$ using an alumina crucible. The TG-DTA simultaneous curves were obtained in the temperature range from 30 up to $720{ }^{\circ} \mathrm{C}$, using the TA Instruments SDT 2960, and a crucible of $\alpha-\mathrm{Al}_{2} \mathrm{O}_{3}$.

XRD analyses were carried out using a diffractometer Mini Flex II X-ray diffractometer-Rigaku ${ }^{\circledR}, \mathrm{Cu} \mathrm{K} \alpha=$ $1.54184 \AA$, $\left(3 \leq 2 \theta \leq 40^{\circ}\right)$, step $=0.05^{\circ}$, an accelerating voltage of $40 \mathrm{kV}$, and a beam current of $15 \mathrm{~mA}$.

\section{SEM and optical images}

The solid samples prepared as described above, pure clay SWy-1, composites SWy-1:8-HQ and SWy-1:8-HQ$\mathrm{Fe}(\mathrm{III})$, were investigated with a scanning electron microscope (SEM), Top Con-SM 300 Instrument. The solid sample was placed onto a carbon tape and covered with a conductive gold coating. SEM images were taken with secondary electrons and $10 \mathrm{kV}$, magnification of $3000 \times$. The optical images were obtained with a digital microscope-Dino Lite Plus AM-313, magnification of $200 \times$.

\section{Results and discussion}

\section{Thermal and $X$-ray diffraction (XRD) studies of the $\left\{[>\mathrm{Si}-\mathrm{O}]_{\mathrm{n}}\left[\mathrm{Fe}(\mathrm{III})\left(\mathrm{OH}_{2}\right)_{3}:(8-\mathrm{HQ})_{\mathrm{k}}\right]\right\}^{3-\mathrm{n}-\mathrm{k}}$ composite or [SWy-1: $\left.\mathrm{Fe}(\mathrm{III})\left(\mathrm{OH}_{2}\right)_{3}-8 \mathrm{HQ}\right]$}

Thermal analyses (Fig. 1, simultaneous TG/DTG-DTA), were used to investigate the $\left\{[>\mathrm{Si}-\mathrm{O}]_{\mathrm{n}}\left[\mathrm{Fe}(\mathrm{III})\left(\mathrm{OH}_{2}\right)_{3}:(8-\right.\right.$ $\left.\left.\mathrm{HQ})_{\mathrm{k}}\right]\right\}^{3-\mathrm{n}-\mathrm{k}}$ ternary composite in two different atmospheres: oxidizing air atmosphere and inert $\left(\mathrm{N}_{2}\right)$. XRD data (Table 1) were used combined with TG, SEM and optical images, UV spectroscopy, and cyclic voltammetry (CV) allowing the possible structure of the ternary clay complex to be proposed. UV spectroscopy and cyclic voltammetry results will be discussed later.

Figure 1 shows that volatile species were removed from the surface of the ternary composite and it was possible to identify the stages of the composite degradation as a 
Fig. 1 DTG-DTA simultaneous curves for the ternary solid complex. $\{[>\mathrm{Si}-$ $\mathrm{O}]_{\mathrm{n}}\left[\mathrm{Fe}(\mathrm{III})\left(\mathrm{OH}_{2}\right)_{3}:(8-\right.$ $\left.\left.\mathrm{HQ})_{\mathrm{k}}\right]\right\}^{3-\mathrm{n}-\mathrm{k}}$-DTG curve: a oxidizing atmosphere, and DTA curves: b (solid line) oxidizing atmosphere; c (continuous line) inert atmosphere of $\mathrm{N}_{2} ; \mathbf{d}$ as in a previously heated to $270{ }^{\circ} \mathrm{C}$ and holding by $t=5 \mathrm{~min}$ and after reheated ramp of temperature $T=30-720{ }^{\circ} \mathrm{C}$. $m_{\text {sample }}=7.0 \mathrm{mg}$; $\beta=20{ }^{\circ} \mathrm{C} \mathrm{min}{ }^{-1}$; synthetic air flow $=50 \mathrm{~mL} \mathrm{~min}^{-1}$

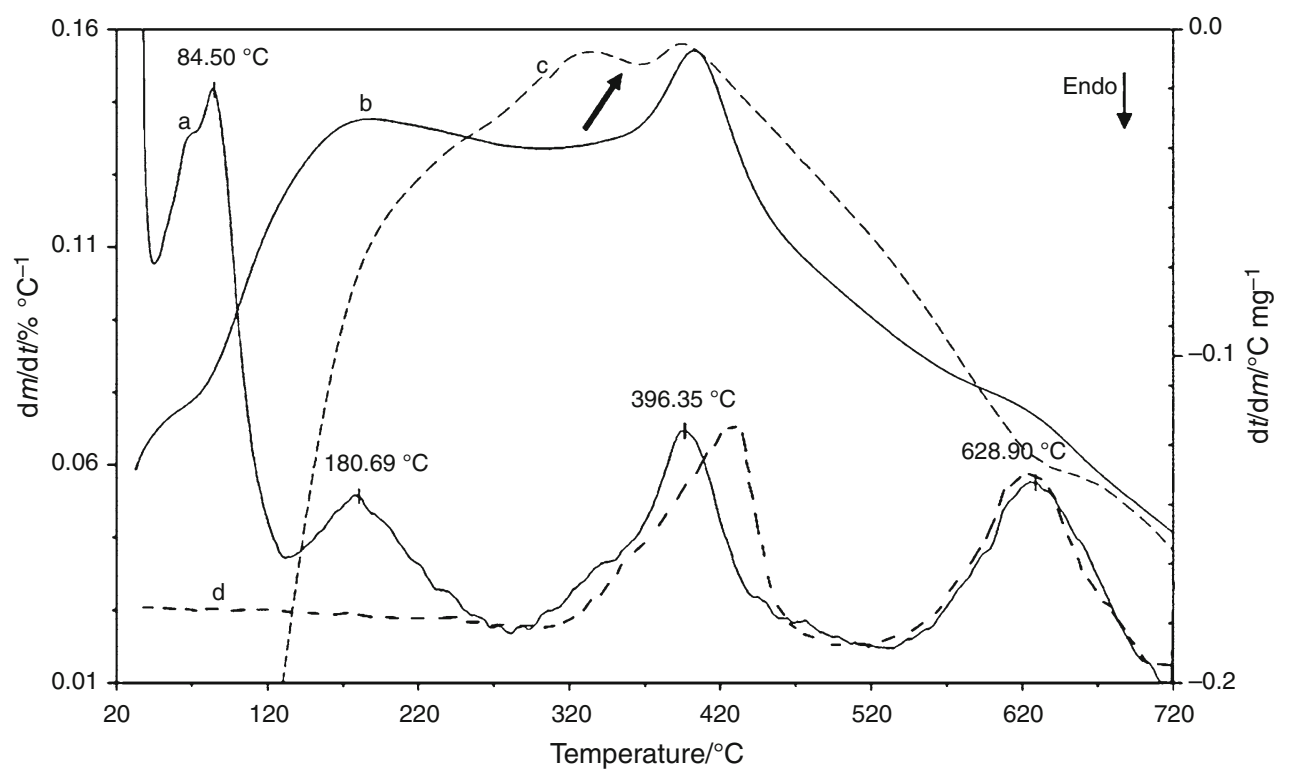

Table $1 d_{001}$ XRD data obtained for different clay composites

\begin{tabular}{llll}
\hline Composite & $d_{001} / \AA$ & $\Delta d_{001} / \AA^{\mathrm{a}}$ & Remarks \\
\hline SWy-1 & 12.17 & - & $\mathrm{H}_{2} \mathrm{O}_{\text {interlayer }}$ \\
{$[\mathrm{SWy}-1: 8-\mathrm{HQ}]$} & 13.45 & 1.28 & 8 - $\mathrm{HQ}_{\text {interlayer not in excess }}$ \\
{$[\mathrm{SWy}-1: 8-\mathrm{HQ}]-\mathrm{Fe}(\mathrm{III})$} & 16.99 & 3.54 & Complex $_{\text {interlayeranhydrous }}$ \\
{$[\mathrm{SWy}-1: 8-\mathrm{HQ}]-\mathrm{Fe}(\mathrm{III})\left(\mathrm{OH}_{2}\right)_{3}$} & 18.22 & 4.77 & Complex \\
\end{tabular}

${ }^{\mathrm{a}} \Delta d_{001}=\left(d_{001}\right.$ composite $\left.-d_{001}[\mathrm{SWy}-1]\right)$-all composites were prepared by the same method

function of the increasing of TG temperature. XRD analyses, TG/DTG-DTA data, and SEM images allowed the evaluation of the changes in the opening of the interlayer spaces $\left(d_{001}\right)$ and the surface structural rearrangement caused by the complex formation between aqueous Fe(III) ions and 8-HQ molecules from the original binary composite, SWy-1:8-HQ [26].

Curves $a$ and $b$ (Fig. 1) represent the simultaneous DTG-DTA curves in an air oxidizing atmosphere. The profile of the curve $a$ shows that the mass loss occurs in four steps, as follows: The first step was attributed to the elimination of solvent molecules adsorbed in the clay system, in an endothermic process $\left(T_{\max }=84.5^{\circ} \mathrm{C}\right)$ occurring in the temperature range between 35 and $130^{\circ} \mathrm{C}$; the second step was attributed to the endothermic elimination of three water molecules $\left(T_{\text {peak }}=180{ }^{\circ} \mathrm{C}\right)$, previously coordinated with $\mathrm{Fe}(\mathrm{III})$ ions in the ternary complex. This step occurs in the temperature range from 135 to $270{ }^{\circ} \mathrm{C}$; the third step, attributed to the oxidation of the ternary complex, is an exothermic process $\left(T_{\text {peak }}=400{ }^{\circ} \mathrm{C}\right)$ with elimination of only one molecule of 8 -HQ, which is coordinated with the $\mathrm{Fe}$ (III) ion as quinolone $N$-oxide ( $\mathrm{O} \leftarrow: 8-\mathrm{HQ}$ ) product [31] and occurring in the temperature range from 290 to $520{ }^{\circ} \mathrm{C}$; and the fourth stage, collapse of the lamellar structure, with simultaneous water (dihydroxylation-endothermic process) [32] and $\mathrm{CO}_{2}$ and $\mathrm{H}_{2} \mathrm{O}$ elimination from residues of 8-HQ molecules (exothermic process) trapped in the interlayer spaces $\left(T_{\text {peak }}=630{ }^{\circ} \mathrm{C}\right)[26]$.

Curve d (Fig. 1) shows DTG obtained after a pretreatment to water removal from the sample, by applying isothermal heating at $T_{\text {iso }}=270{ }^{\circ} \mathrm{C}$ during a hold time of $t=5 \mathrm{~min}$. After the previous treatment, a new DTG curve was run in the same experimental conditions as the curve a. The DTG profile shows an increase in the $T_{\text {peak }}$, observed at $T_{\text {peak }}=396{ }^{\circ} \mathrm{C}$, of $\Delta T \sim 30{ }^{\circ} \mathrm{C}$ for the removal of the 8-HQ molecules, after eliminating the total of water molecules (absence of the peak on $T_{\text {peak }}=180^{\circ} \mathrm{C}$ ). In this way, this increase in the $T_{\text {peak }}$ value was ascribed to the close down of the interlayer, which is in agreement with XRD (Table 1).

The thermal experiments conducted under different experimental conditions aim to differentiate the thermal process of 8-HQ removal from the ternary complex. Thus, in $\mathrm{N}_{2}$ atmosphere, the curve $\mathrm{c}$ in Fig. 1 showed an endothermic process with slow kinetic, with $T_{\text {peak }}=430{ }^{\circ} \mathrm{C}$ 
and occurring from 380 to $460{ }^{\circ} \mathrm{C}$, which was ascribed to the removal of 8-HQ molecules complexed (distillation process, see arrow).

In an oxidizing atmosphere, the curve $b$ in Fig. 1 showed an opposite behavior in comparison to the curve obtained in $\mathrm{N}_{2}$ atmosphere. From curve $b$, we observed a peak $T_{\max }=400{ }^{\circ} \mathrm{C}$, which is exothermic in contrast to the endothermic peak observed at $T_{\text {peak }}=430{ }^{\circ} \mathrm{C}$; curve $b$ still shows a rapid kinetic process. This thermal behavior is possibly caused by the exothermic oxidation process involving the species present on the surface with the consequent for-

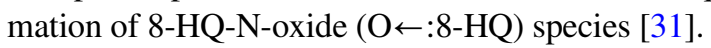

Once the apparent stoichiometry of the ternary complex $\left\{[>\mathrm{Si}-\mathrm{O}]_{\mathrm{n}}\left[\mathrm{Fe}(\mathrm{III})\left(\mathrm{OH}_{2}\right)_{3}:(8-\mathrm{HQ})_{\mathrm{k}}\right]\right\}^{3-\mathrm{n}-\mathrm{k}}$ has been suggested, the next step was to investigate the apparent geometry of the system. Thus, XRD data were obtained for the different systems: a) pure clay (SWy-1) represented as a silanol group $[>\mathrm{Si}-\mathrm{O}]$ in the binary and ternary composite; $b$ ) binary composite $\left.\left.\left(\left\{[>\mathrm{Si}-\mathrm{O}]_{\mathrm{n}}:(8-\mathrm{HQ})_{\mathrm{k}}\right]\right\}^{\mathrm{n}-\mathrm{k}}=\mathrm{SWy}-1: 8-\mathrm{HQ}\right) ; \mathrm{c}\right)$ anhydrous ternary composite $\left(\left\{[>\mathrm{Si}-\mathrm{O}]_{\mathrm{n}}\left[\mathrm{Fe}(\mathrm{III}):(8-\mathrm{HQ})_{\mathrm{k}}\right]\right\}^{3-\mathrm{n}}=\right.$ [SWy-1:8-HQ]-Fe(III)); and d) hydrated ternary composite $\quad\left(\left\{[>\mathrm{Si}-\mathrm{O}]_{\mathrm{n}}\left[\mathrm{Fe}(\mathrm{III})\left(\mathrm{OH}_{2}\right)_{3}:(8-\mathrm{HQ})_{\mathrm{k}}\right]\right\}^{3-\mathrm{n}}=[\mathrm{SWy}-1: 8-\mathrm{HQ}]-\right.$ $\mathrm{Fe}(\mathrm{III})\left(\mathrm{OH}_{2}\right)_{3}$; all composites were prepared in the same way (Table 1).

The data shown in Table 1 demonstrated that the interlayer space opening increased steadily in the transition from pure clay (SWy-1) to the binary composite, by the intercalation of 8-HQ molecules into SWy-1 and later with the complexation of Fe(III) ions by the 8-HQ molecules. So, the maximum aperture of the interlayer spaces occurs due to the complexation of Fe(III) ions by 8-HQ molecules. The major interlayer opening value $\left(\Delta d_{001}=4.77 \AA\right)$, observed for the ternary composite, is greater than the opening obtained for the binary composite, prepared in an excess of 8-HQ molecules $\left(\Delta d_{001}=4.15 \AA\right)$ [26, 28]. On the other hand, when the binary composite was prepared with a low amount of 8-HQ molecules, the interlayer opening value is $\Delta d_{001}=1.28 \AA$ [26]. By this way, the binary composites formed showed, respectively, an angular package arrangement $\left(\Delta d_{001}=4.15 \AA\right)$ and a flat arrangement $\left(\Delta d_{001}=1.28 \AA\right)$ for the 8-HQ molecules [26].

The presence of water molecules in the ternary complex, removed at $T_{\text {peak }}=180{ }^{\circ} \mathrm{C}$, according to the DTG-DTA curve profile, was attributed to $\left[\mathrm{Fe}\left(\mathrm{OH}_{2}\right)_{3}\right]^{3+}$ aqueous ions, due to the strong Lewis acid character of Fe(III) ions. Thus, $\mathrm{Fe}$ (III) ions carry with them coordinating water molecules retained, at least partially, during the formation of the ternary composite (Fig. 1, curve a). So, when these water molecules were totally removed, at $T_{\text {iso }}=270{ }^{\circ} \mathrm{C} / 5 \mathrm{~min}$ (Fig. 1, curve d), the ternary complex interlayer is closed by $\Delta d_{001}=1.23 \AA$. This interlayer closing traps the 8-HQ molecules hindering the 8-HQ removal from the ternary complex, shifting its decomposition peak temperature of a $\Delta T=35^{\circ} \mathrm{C}\left(T_{\text {peak }}=430{ }^{\circ} \mathrm{C}\right.$; Fig. 1 , curve d $)$.

The XRD behavior of these different composites with the thermal water removal reflects and corroborates the proposed stoichiometry for the ternary composite.

\section{Clay binary film investigation}

To verify the mechanical stability of the thin solid film of SWy-1:8-HQ, mechanically deposited on Pt disk electrode surface of the geometric area, $A_{\text {geom }}=0.0314 \mathrm{~cm}^{2}, 80$ consecutive cyclic voltammetric cycles and at different scan rate values $(25 \leq v \leq 200) \mathrm{mV} \mathrm{s}^{-1}$ were obtained. Figure 2 shows the profile of the last $\mathrm{CV}$ cycle for the different $v$ values and evidences the absence of a significant difference among them. The CV profiles show two peaks, one in the cathodic branch, peak $\mathrm{A}, E=-0.395 \mathrm{~V}$, and the other in the anodic branch of low intensity, peak B, $E=0 \mathrm{~V}$. With the increase in $v$, the current of peak A was intensified. At the same time, the anodic peak, B, although with lower current intensity was also intensified slightly with the increase in $v$ values. The electrochemical process for peak $\mathrm{A}$ was investigated and the relation $i_{\mathrm{p}}^{\mathrm{A}}$ versus $v$ [33] shows to be linear. This behavior suggests that 8-HQ species are adsorbed into the clay surface, according to UV spectra obtained for the same binary composite in a water suspension system.

Figure 3 shows the UV spectra obtained for binary and ternary aqueous suspensions systems prepared in the same experimental way that samples used for obtaining the simultaneously TG-DTA curves and XRD patterns. The spectra are from an aqueous suspension of the binary

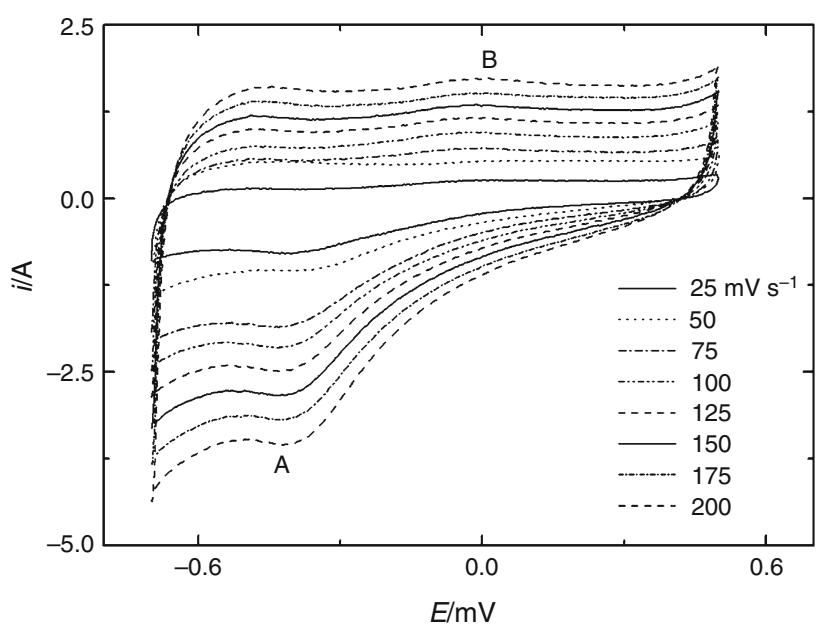

Fig. 2 Last cycles of CVs obtained for SWy-1:8-HQ-modified electrode, $(25 \leq v \leq 200) \mathrm{mV} \mathrm{s}^{-1}$ in $0.100 \mathrm{~mol} \mathrm{~L}^{-1} \mathrm{KCl}$. $E_{\text {start }}=$ $E_{\text {end }}=-0.7 \mathrm{~V} \quad$ and $\quad E_{\text {inv. }}=0.5 \mathrm{~V} ; \quad T=(25 \pm 2)^{\circ} \mathrm{C}$; $A_{\text {geom }}=0.0314 \mathrm{~cm}^{2} ; n=10$ 


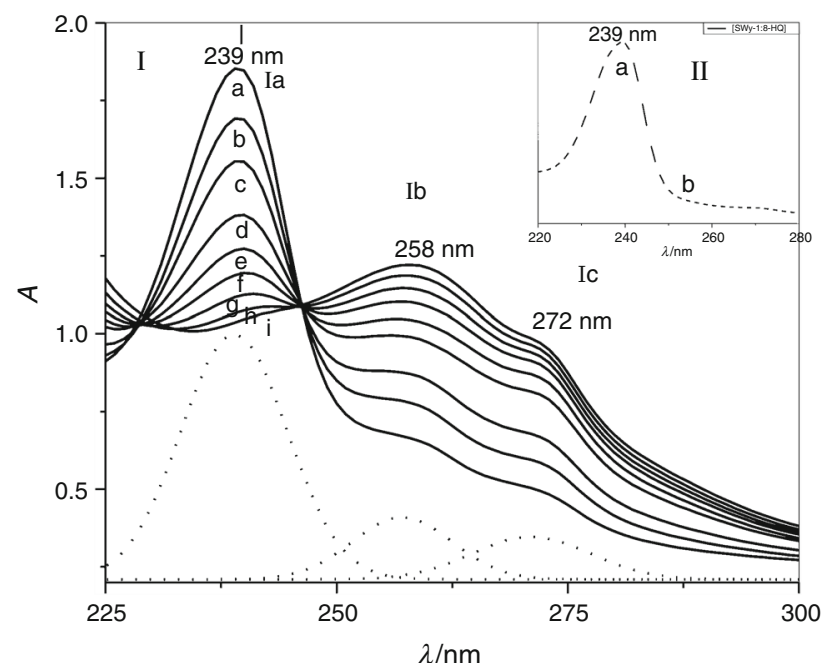

Fig. 3 I Absorption spectra obtained for the [SWy-1:8-HQ]-Fe(III) system by increasing the $C_{\mathrm{Fe}(\text { III })}$ ions $\left(1.0<C_{\mathrm{Fe}(\mathrm{III})}<16.1\right) \times 10^{-6}$ $\mathrm{mol} \mathrm{L}{ }^{-1}$ and II for [SWy-1:8-HQ], $C_{8-\mathrm{HQ}}=6.0 \times 10^{-5} \mathrm{~mol} \mathrm{~L}^{-1}$. $T=(25 \pm 2){ }^{\circ} \mathrm{C}$ and (solid line) deconvolution of curve $d$

composite $S W y-1: 8-H Q$ in the presence of different $\mathrm{Fe}$ (III) ion concentrations, $\left(1.0<C_{\mathrm{Fe}(\mathrm{III})}<16.1\right) \times 10^{-6}$ $\mathrm{mol} \mathrm{L}^{-1}$ (Fig. 3I, curves a-i) and in the absence of $\mathrm{Fe}(\mathrm{III})$ ions (Fig. 3II). Figure 3 II shows spectra of a freshly resuspended $S W y-1: 8-H Q$ binary composite. This UV spectra shows a peak at $\lambda=239 \mathrm{~nm}$ (peak a) attributed to a hydrophobic dimeric species, $(8-\mathrm{HQ})_{2}$, which is of a maximum intensity, and a peak of lower intensity near $\lambda=252 \mathrm{~nm}$ attributed to a monomeric species, 8-HQ adsorbed into the clay [27], according to the equation:

$2(8-\mathrm{HQ}) \leftrightarrows(8-\mathrm{HQ})_{2} ; \quad k=1.0 \times 10^{7}[26,27]$

According to Fig. 3I, the increase in $C_{\mathrm{Fe}(\mathrm{III})}$ ions causes the appearance of new absorption peaks in the UV range of $(250 \leq \lambda \leq 280) \mathrm{nm}$ positioned at $\lambda=258$ and $272 \mathrm{~nm}$, suggesting the formation of a new species in accordance with the TG-DTA data, which was attributed to the ternary composite, $S W y-1: 8-H Q-F e(I I I)$. To obtain these spectra, a large concentration of 8 -HQ was used to increase the quantity of dimeric species, $(8-\mathrm{HQ})_{2}$, adsorbed onto the SWy-1 surface (Fig. 3I, curve a)).

Figure 4 shows SEM and optical images obtained for the binary and ternary solid samples, where the changes in morphology and roughness after the addition of 8-HQ molecules into SWy-1 (Fig. 4I-III) to form the binary composite can be seen and $\mathrm{Fe}(\mathrm{III})$ ions into the previous binary composite, $S W y-1: 8-H Q$. These morphological changes are in agreement with XRD data (Table 1).

The analysis of spectra shown in Fig. 3 revealed three absorption peaks: Ia, Ib, and Ic in the range of $(225 \leq \lambda \leq 300) \mathrm{nm}$. The peak Ia $(\lambda=239 \mathrm{~nm})$ refers to the dimeric species (8-HQ) $)_{2}$ as described above [26-28].
This peak showed a decrease on its absorption intensity with the increase in $C_{\mathrm{Fe}(\mathrm{III})}$, while the other two peaks are intense peaks at $\lambda=258 \mathrm{~nm}$ (Ib) and $\lambda=272 \mathrm{~nm}$ (Ic). In order to confirm the presence of these two peaks, a deconvolution process was applied to curve d, Fig. 3, represented by the dotted lines. The deconvoluted spectrum helped to confirm the effective presence of Ib and Ic peaks due to the binary composite complex with $\mathrm{Fe}(\mathrm{III})$ ions. It should be noted that these peaks (Ib and Ic) are absent in the UV spectra of binary composite, $S W y-1: 8-H Q$ (Fig. 3II).

The appearance and intensification of peak $\mathrm{Ib}$ at $\lambda=258 \mathrm{~nm}$ was effectively due to the formation of the new ternary composite [SWy-1:8-HQ]-Fe(III). On the other hand, the signal observed at $\lambda=272 \mathrm{~nm}$ (peak Ic) could not be attributed to the formation of a second new species, but ascribed to an aromatic ring $\sigma \rightarrow \pi^{*}$-type transition [28, 34], suggesting the formation of a bi-dentate complex, with the participation of coordination sites: pyridine and $\mathrm{N}-\mathrm{OH}-$ phenolic group of 8-HQ molecules. This proposal was based on the intensification of the signal observed at $\lambda=272 \mathrm{~nm}$ with a more effective participation of the phenolic - $\mathrm{OH}$ group to the complex formation [35]. This is because the pyridine groups probably interact with the acid sites of the clay, considering that the $\mathrm{pKa}$ value of the pyridine ring is 5.13 [36-38].

The ternary complex formation was indeed confirmed by viewing the color change of the binary composite from pale green to intense navy blue after the addition of $\mathrm{Fe}(\mathrm{III})$ ions (Fig. 4IV-VI). This fact was registered by optical images obtained from solid samples of clay, binary, and ternary composites after complexing the $\mathrm{Fe}(\mathrm{III})$ ions. The intense navy blue color was maintained for long time (2012-2016) in the solid state after centrifugation and draying the ternary composite (Fig. 4VI).

Parallel experiments run in test tubes using Fe(II) ions instead of $\mathrm{Fe}$ (III) ions and in the presence of a binary clay (SWy-1:8-HQ) suspension showed absence of navy blue color and the original pale green color observed earlier for the binary composite was maintained, suggesting that if the ternary composite of ions $\mathrm{Fe}$ (II) was formed, it does not show any color. This behavior is in agreement with the literature information for the pair redox $\mathrm{Fe}(\mathrm{II}) / \mathrm{Fe}(\mathrm{III})$ ions inside the $\left.[\mathrm{Fe}(\mathrm{III}) /(\mathrm{II}) \text { (1,10-phenanthroline) })_{3}\right]$ aqueous complex $[39,40]$.

\section{Cyclic voltammetry of [Pt-SWy-1:8-HQ]-Fe(III) film-modified electrode}

Figure 5I-III shows the set of cyclic voltammograms (CVs) for different $v$ values obtained for the Pt electrode modified with a thin film of a binary composite (SWy-1:8-HQ) in the 
Fig. 4 SEM and optical images of clay and composites: SWy-1 (I, IV); SWy-1:8-HQ (II, V) and SWy-1:8-HQ-Fe(III) (III, VI). SEM images $(\times 3000)$ : I, II and III; optical images (×200): IV, V and VI
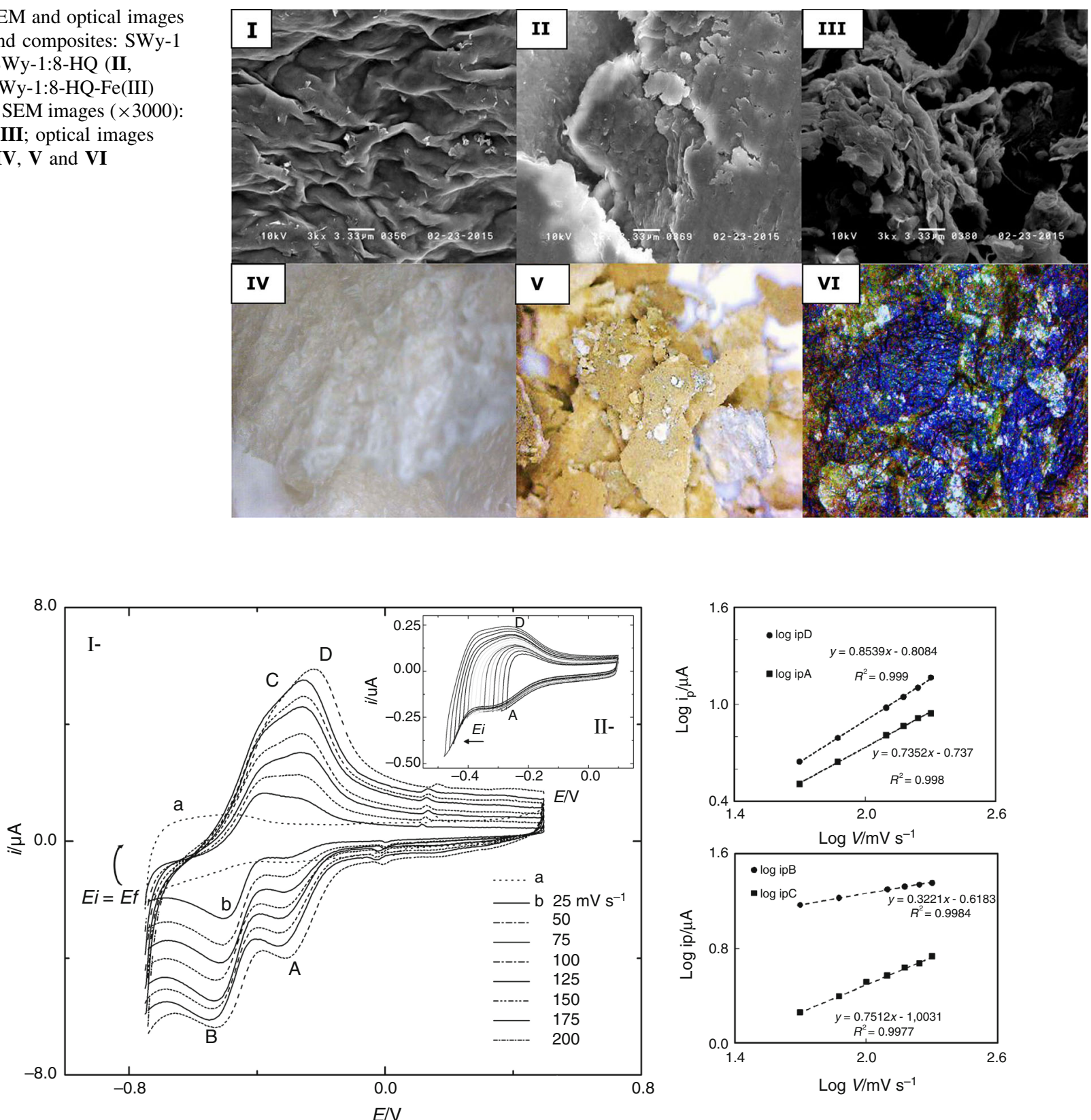

Fig. $5 \mathrm{I} \mathrm{CVs}$ of the modified electrode in absence ( $a$; $v=25 \mathrm{mV} \mathrm{s}^{-1}$ ) and presence (b) of $\mathrm{Fe}(\mathrm{III})$ ions, for $(25 \leq v \leq 200) \mathrm{mV} \mathrm{s}^{-1}$ obtained in $0.1 \mathrm{~mol} \mathrm{~L}^{-1} \mathrm{KCl}$ and $v=25 \mathrm{mV} \mathrm{s}^{-1}$; II $E_{\lambda}$ advance on peak A, $0.100 \mathrm{~mol} \mathrm{~L}^{-1} \mathrm{KCl}$,

presence of $\left(C_{\mathrm{Fe}(\mathrm{III})}=9.74 \times 10^{-6} \mathrm{~mol} \mathrm{~L}^{-1}\right)$ and in the absence of aqueous $\mathrm{Fe}(\mathrm{III})$ ions.

The CVs obtained for Fig. 5I show two pairs of peaks, $\mathrm{A} / \mathrm{D}$ and $\mathrm{B} / \mathrm{C}$, which are mutually interrelated as demonstrated in Fig. 5II. The peak potentials are: $E_{\mathrm{A}}=-0.21 \mathrm{~V}$, $E_{\mathrm{D}}=-0.27 \mathrm{~V}, E_{\mathrm{B}}=-0.47 \mathrm{~V}$, and $E_{\mathrm{C}}=-0.32 \mathrm{~V}$. The pair of peaks $\mathrm{A} / \mathrm{D}$ is separated by a $\Delta E=(62 \pm 3) \mathrm{mV}$ and shows a value of $n=0.95 \pm 0.04$, being then value obtained from the relation of $\Delta E=59.1 / \mathrm{n}$ [41]. This result
$C_{\mathrm{Fe}(\mathrm{III})}=9.74 \times 10^{-6} \mathrm{~mol} \mathrm{~L}^{-1} . \quad E_{\text {start }}=E_{\text {and }}=-0.7 \mathrm{~V} \quad$ and $E_{\text {inv. }}=0.5 \mathrm{~V} ; \quad T=(24 \pm 3){ }^{\circ} \mathrm{C} ; \quad A_{\text {geom }}=0.0314 \mathrm{~cm}^{2}$. $T=(25 \pm 2){ }^{\circ} \mathrm{C} ;$ III $\log i_{\mathrm{p}}$ versus $v$

suggests an electrochemical reversible process; otherwise the relation between $\log i_{\mathrm{p}}$ versus $\log v$ (not shown) suggests an electrochemical process controlled by adsorption.

These results are in agreement with that showed by the UV spectra (Fig. 3), TG-DTA data, SEM images (Fig. 4IIII), optical images (Fig. 4IV-VI), and XRD data (Table 1). As we can see from Table 1, clay interlayer spaces $(d)$ enlarge by $(1.28 \pm 0.04) \mathrm{A}$ in comparison with pure SWy-1, when 8-HQ molecules were inserted into the 
interlayer spaces to form SWy-1:8-HQ binary composite [26]. Likewise, insertion of Fe(III) ions into the interlayer of the binary composite enlarges the space by $(2.49 \pm 0.04)$ A. This interlayer space enlargement consequently generated an expanded new surface on the Ptbased electrode, facilitating ions diffusion from the aqueous solution into the clay ternary composite film.

The second pair of peaks $B / C$, in the potential range of $(-0.37 \leq E \leq-0.79)$ V, Fig. 5, does not have a comparison to the UV data of Fig. 3. The peak separation of $\Delta E=110 \mathrm{mV} \quad\left(C_{\mathrm{Fe}(\mathrm{III})}=2.40 \times 10^{-6} \mathrm{~mol} \mathrm{~L}^{-1} \quad\right.$ and $25 \mathrm{mV} \mathrm{s}^{-1}$ ) and the $\log i_{\mathrm{p}}$ versus $\log v$ (not shown) criterion [33] allowed us to suggest a controlled diffusion process for both peaks, B and C.

In this way, we can tentatively ascribe the appearance and enlargement of the peak separation of $\Delta E=110 \mathrm{mV}$ to an increasing imposed resistance, possibly by the new substrate formed, the ternary composite film: [SWy-1:8$\mathrm{HQ}]-\mathrm{Fe}^{\mathrm{n}+}$, and by the fact that these electrochemical reactions are controlled by a diffusion process.

Thus, peaks B/C are feasible to ascribe to a different electrochemical process than that observed for peaks A/D, now occurring on a new surface. This new surface has a different morphology, which was confirmed by SEM (Fig. 4I-III) and optical (Fig. 4IV-VI) images, enabling a new process to occur on the new electrode surface. The optical image makes the complex formation evident as the ternary composite observed by the apparent color change from a pale green to an intense navy blue and the structural change of the ternary composite in comparison with the binary one, as also confirmed by XRD data (Table 1).

Now it is important to note that DTG-DTA results show the formation of only one complex specie present on the surface of the investigated solid-state ternary composite, represented by the $T_{\text {peak }}=396{ }^{\circ} \mathrm{C}$, in DTA curve (Fig. 1a-d). So, there is internal evidence that the pair of peaks $B / C$ is derived from an electrochemical reaction not occurring by surface control, but with species presents in the solution, as suggested by the plotting $\log i_{\mathrm{p}}$ versus $\log v$ (Fig. 5II-IV). Considering the behavior shown by peak B (Fig. 5I), preliminary experiments were carried out to evaluate the relationship of $i_{\mathrm{pB}}^{\mathrm{c}}$ versus $C_{\mathrm{Fe}(\mathrm{III})}$, in the absence of $\mathrm{O}_{2}$ (figure not shown). A linear behavior was observed: $y=$ $-2.698 x-1.673, r=0.9990$, for a range of $(2.4 \leq$ $\left.C_{\mathrm{Fe}(\mathrm{III})} \leq 49.8\right) \mu \mathrm{mol} \mathrm{L}{ }^{-1}$, showing a: $1-\operatorname{good}$ sensitivity, $S=25.1 \mu \mathrm{A} / \mu \mathrm{mol} \mathrm{L}{ }^{-1} ; 2$-lower detection limit, $\mathrm{LOD}=(2.40 \pm 0.10) \mu \mathrm{mol} \mathrm{L}{ }^{-1} \quad$ [42]; and 3-good repeatability, $r=4.0 \%$, for $n=5$ [43]. So, these parameter values are in agreement with those shown in the literature [42-45]. Thus, there are efforts in progress in our laboratory to improve the analytical parameters, applying the more sensitive square wave voltammetry (SWV) technique, and subsequent method validation.
Considering the relevant information came from UV and the others techniques used to characterize the film surface before and after inserting $\mathrm{Fe}(\mathrm{III})$ ions into the binary composite, the electrochemical behavior of the peaks A/D and B/C, shown in Fig. 5, was investigated by the application of diagnostic criteria for $\mathrm{CE}$ and $\mathrm{EC}$ mechanisms [41]. The proposed mechanisms for these reaction steps are shown further on in this text.

\section{Homogeneous reactions study using Pt-SWy-1: 8-HQ-Fe(III) film-modified electrode}

Figure 5I shows CVs obtained for different scan rates which were used to (1) characterize the origin of the coupled redox peaks, $\mathrm{A} / \mathrm{D}$ and $\mathrm{B} / \mathrm{C}$; (2) confirm the electrochemical dependence between the coupled peaks; and (3) elucidate the mechanisms of electrochemical reactions. Figure 5II shows CVs obtained using $C_{\mathrm{Fe}(\mathrm{III})}=2.40 \times 10^{-6} \mathrm{~mol} \mathrm{~L}^{-1}$ and $50 \mathrm{mV} \mathrm{s}^{-1}$ and inverting the scanning potential $\left(E_{\lambda}\right)$ at different potential values: for peak $\mathrm{A}\left(0 \leq E_{\lambda} \leq-0,34\right) \mathrm{V}$ and for peak $\mathrm{B}\left(-0.34 \leq E_{\lambda} \leq-0.75\right) \mathrm{V}$.

Figure 5IV, V shows the $\log i_{\mathrm{p}}^{\mathrm{a}}$ versus $\log v$ plots for the $\mathrm{A} / \mathrm{D}$ and $\mathrm{B} / \mathrm{C}$ pair of peaks, respectively and suggests that peaks $\mathrm{A}$ and $\mathrm{D}$ are controlled by adsorption, corroborating the data obtained by UV, and peaks B and C are controlled by diffusion. Another important aspect was the linearity of anodic $\left(E_{\mathrm{p}}^{\mathrm{a}}\right)$ and cathodic $\left(E_{\mathrm{p}}^{\mathrm{c}}\right)$ peak potentials, $E_{\mathrm{p}}$, with $v$ for both pairs of peaks (A/D and B/C), confirming the reversibility of the processes [41].

The current function $\left(i_{\mathrm{p}} / \mathrm{v}^{1 / 2}\right)$ versus $v$ and the anodic/cathodic current peak ratio $\left(\mathrm{i}_{\mathrm{p}}^{\mathrm{a}} / \mathrm{i}_{\mathrm{p}}^{\mathrm{c}}\right)$ versus $v$ were used to elucidate the electrochemical mechanisms responsible for the two pairs of peaks, A/D and B/C. Such relationships were initially obtained for the pair of peaks $A$ and $D$ and are presented in Fig. 6a, b, suggesting that a CE type mechanism [37] is applied. This means that a fast precedent chemical reaction is followed by a fast one-electron charge transfer process [41].

Thus, considering only the aqueous species of $\left[\mathrm{Fe}\left(\mathrm{OH}_{2}\right)_{6}\right]^{3+}>95 \%$, present in aqueous solution at $\mathrm{pH} 6$ [37, 38], a possible mechanism is being suggested as follows:

1. Chemical step occurring with the formation of the ternary complex by a fast and reversible chemical reaction occurring on the surface of clay binary composite (see Fig. 7I-CE):

$$
\left\{\mathrm{Pt} /[>\mathrm{Si}-\mathrm{O}]_{\mathrm{n}}\left[\mathrm{Fe}(\mathrm{III})\left(\mathrm{OH}_{2}\right)_{\mathrm{m}}-(8-\mathrm{HQ})_{\mathrm{k}}\right]\right\}^{3-\mathrm{n}-\mathrm{k}},
$$

where $n=$ number of silanol groups; $m=$ number of water molecules (the number of water and 8-HQ 

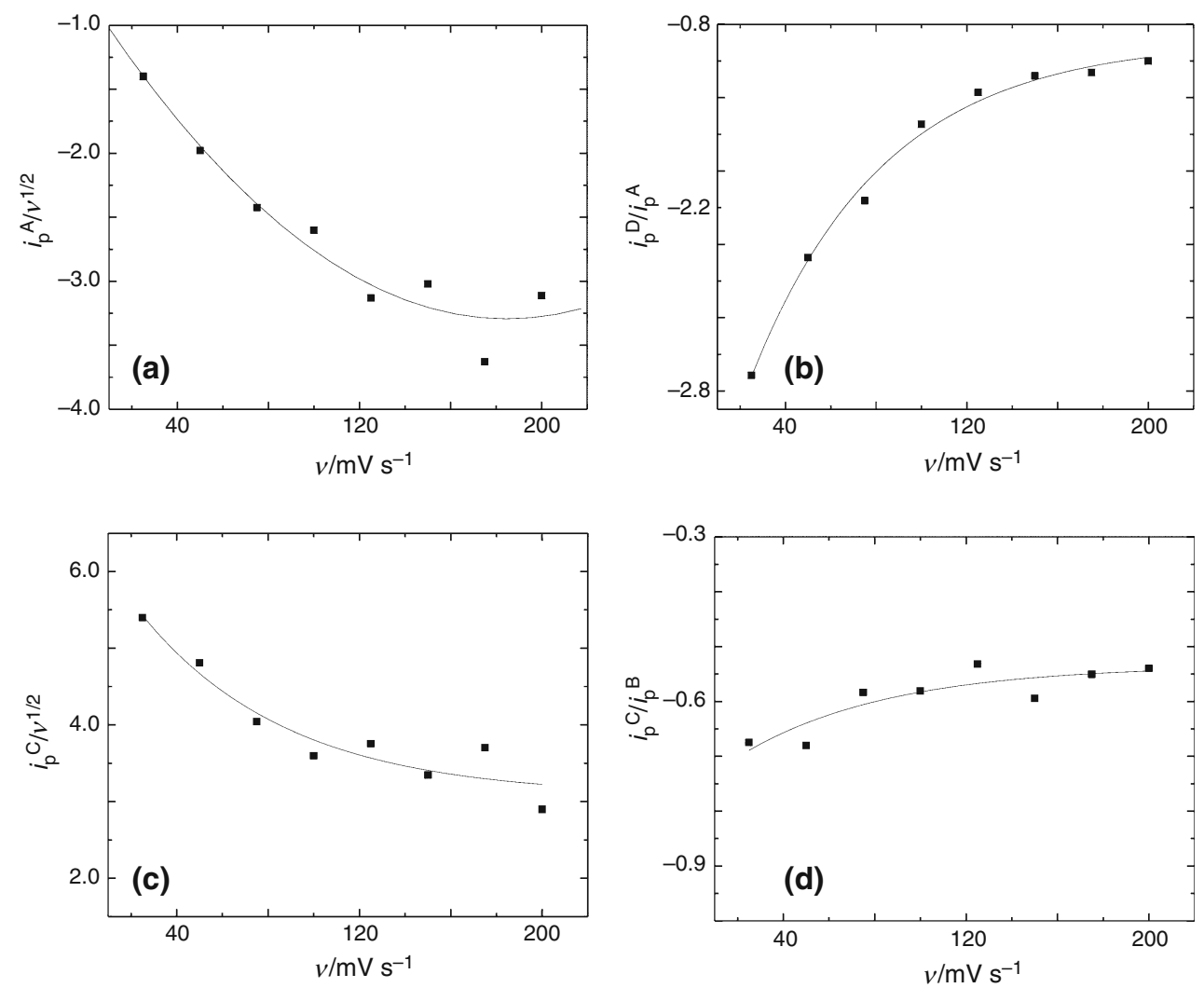

Fig. 6 Current function versus $v$ plots for the SWy-1:8-HQ-Fe(III) ternary composite to the peaks: A and $\mathrm{D}, \mathbf{a} i_{\mathrm{p}}^{\mathrm{A}} / v^{1 / 2}$ versus $v ; \mathbf{b} i_{\mathrm{p}}^{\mathrm{D}} / i_{\mathrm{p}}^{\mathrm{A}}$ versus $v ;(25 \leq v \leq 200) \mathrm{mV} \mathrm{s}^{-1}$; and peaks $\mathrm{B}$ and $\mathrm{C} \mathrm{c} i_{\mathrm{p}}^{\mathrm{C}} / v^{1 / 2}$ versus

$v ; \mathbf{d} i_{\mathrm{p}}^{\mathrm{C}} / i_{\mathrm{p}}^{\mathrm{B}}$ versus $v ;(25 \leq v \leq 200) \mathrm{mV} \mathrm{s}^{-1} ; C_{\mathrm{Fe}(\mathrm{III})}=2.40 \times 10^{-6}$ $\mathrm{mol} \mathrm{L}{ }^{-1} ; T=(24 \pm 3){ }^{\circ} \mathrm{C}$

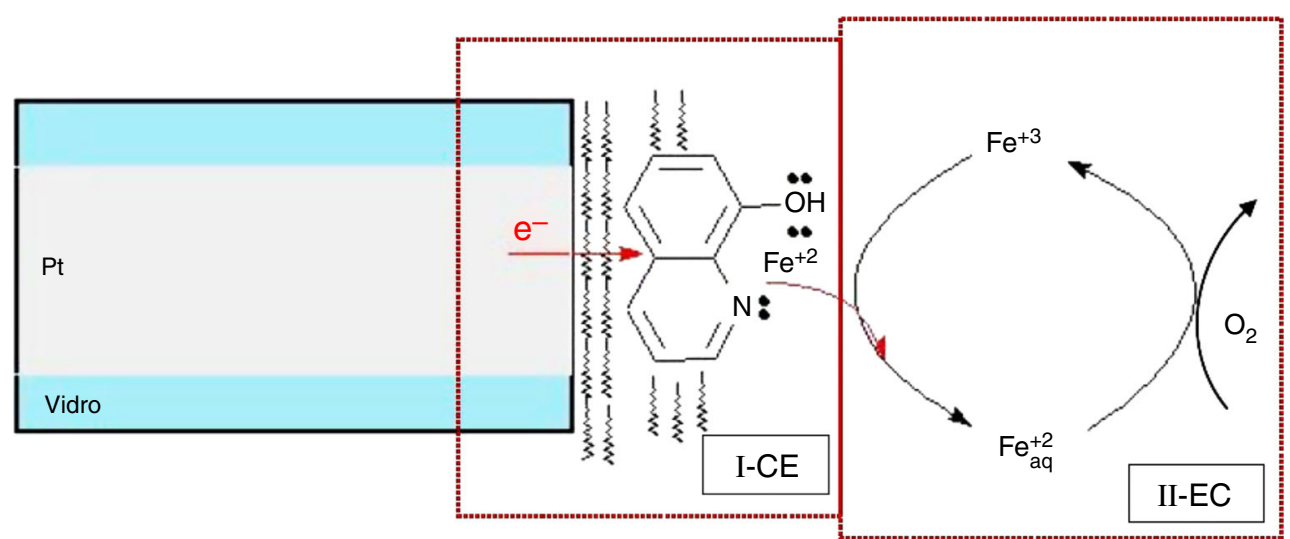

Fig. 7 Scheme of the processes occurring on the electrode surface in an aqueous solution. I-CE formation of the complex $\{\mathrm{Pt} /[>\mathrm{Si}-$ $\left.\mathrm{O}]_{\mathrm{n}}\left[\mathrm{Fe}(\mathrm{III})\left(\mathrm{OH}_{2}\right)_{\mathrm{m}}:(8-\mathrm{HQ})_{\mathrm{k}}\right]\right\}^{3-\mathrm{n}-\mathrm{k}}$ and reduction of $\mathrm{Fe}(\mathrm{III})$ to $\mathrm{Fe}(\mathrm{II})$ species to form $\left\{\mathrm{Pt} /[>\mathrm{Si}-\mathrm{O}]_{\mathrm{n}}\left[\mathrm{Fe}(\mathrm{II})\left(\mathrm{OH}_{2}\right)_{\mathrm{m}}:(8-\mathrm{HQ})_{\mathrm{k}}\right]\right\}^{2-\mathrm{n}-\mathrm{k}}$; II-EC

molecules was estimated by TG/DTG primary technique); $k=$ number of molecules of 8-HQ [37].

2. Electrochemical step, a reversible one-electron charge transfer $(n=1)$ reaction, involves the $\mathrm{Fe}(\mathrm{III})$ ion. The metallic center of the complex is reduced to $\mathrm{Fe}$ (II) ion, generating a new ternary species (see Fig. 7I-CE): reduction of the aqueous $\mathrm{Fe}(\mathrm{III})$ species on the modified electrode $\{\mathrm{Pt} /$ $\left.[>\mathrm{Si}-\mathrm{O}]_{\mathrm{n}}\left[\mathrm{Fe}(\mathrm{II})\left(\mathrm{OH}_{2}\right)_{\mathrm{m}}:(8-\mathrm{HQ})_{\mathrm{k}}\right]\right\}^{2-\mathrm{n}-\mathrm{k}}$ and subsequent oxidation of $\mathrm{Fe}(\mathrm{II})$ to $\mathrm{Fe}(\mathrm{III})$ aqueous species by $\mathrm{O}_{2}$ on the electrode surface

$$
\left\{\mathrm{Pt} /[>\mathrm{Si}-\mathrm{O}]_{\mathrm{n}}\left[\mathrm{Fe}(\mathrm{II})\left(\mathrm{OH}_{2}\right)_{\mathrm{m}}:(8-\mathrm{HQ})_{\mathrm{k}}\right]\right\}^{2-\mathrm{n}-\mathrm{k}} \text {, }
$$

where $m=3$, number of $\mathrm{H}_{2} \mathrm{O}$ molecules and $k=1$, 8-HQ molecule.

The same procedure was applied to the $\mathrm{B} / \mathrm{C}$ couple of peaks. The graphics of the current function $\left(i_{\mathrm{p}}^{\mathrm{c}} / v^{1 / 2}\right)$ versus 
$v$ and $\left(i_{\mathrm{p}}^{\mathrm{D}} / i_{\mathrm{p}}^{\mathrm{A}}\right)$ versus $v$ are shown in Fig. $6 \mathrm{c}, \mathrm{d}$ and suggest the presence of an EC-type mechanism [33] that consists of two steps (see Fig. 7II-EC): a reversible one-electron charge transfer reaction followed by a fast and reversible chemical reaction.

Now, considering the new substrate formed on the surface of the modified electrode $\left\{\mathrm{Pt} /[>\mathrm{Si}-\mathrm{O}]_{\mathrm{n}}\left[\mathrm{Fe}(\mathrm{II})\left(\mathrm{OH}_{2}\right)_{3}\right.\right.$ : $\left.\left.(8-\mathrm{HQ})_{\mathrm{k}}\right]\right\}^{2-\mathrm{n}-\mathrm{k}}$, as previously discussed, and the species present in aqueous solution, $\left[\mathrm{Fe}\left(\mathrm{OH}_{2}\right)_{6}\right]^{3+}$ ions, the following mechanism is suggested:

1. The new substrate, $\left\{\mathrm{Pt} /[>\mathrm{Si}-\mathrm{O}]_{\mathrm{n}}\left[\mathrm{Fe}(\mathrm{II})\left(\mathrm{OH}_{2}\right)_{3}\right.\right.$ : $\left.\left.(8-\mathrm{HQ})_{\mathrm{k}}\right]\right\}^{2-\mathrm{n}-\mathrm{k}}$, acts as a facilitator of electron transfer from the electrode to the aqueous $\mathrm{Fe}(\mathrm{III})$ ions in the diffuse layer, reducing $\mathrm{Fe}$ (III) ions to $\mathrm{Fe}(\mathrm{II})$ ion species, giving rise to the peak B (see Fig. 5I);

2. Afterward, the Fe(II) species (formed in 1) are oxidized to $\mathrm{Fe}$ (III) ions species on the substrate to giving rise to the peak C (see Fig. 5I, II); then, 3) a chemical step has appeared as an homogeneous reaction of Fe(II) ions with $\mathrm{O}_{2}$ molecules, partially oxidizing $\mathrm{Fe}(\mathrm{II})$ ions (initially produced in peak B) to $\mathrm{Fe}(\mathrm{III})$ ions. This $\mathrm{O}_{2}$ molecules were incorporated by a counterflow stream in the $\mathrm{N}_{2}$ stream; this reaction precedes the electrochemical reaction, peak $\mathrm{C}$, in the reverse scan, consequently reducing the current intensity of peak $\mathrm{C}$.

The low influence of residual content of $\mathrm{O}_{2}$ on the current intensity of peak $\mathrm{C}$ was ascribed to a decrease in the experimental time by increasing $v$; this electrochemical influence was absent when the experiment was performed in a $\mathrm{N}_{2}$ atmosphere.

Thus, based on previous discussion, it was possible to propose a scheme to represent the electrochemical process developed on the modified $\mathrm{Pt}$ electrode, $\left\{\mathrm{Pt} /[>\mathrm{Si}-\mathrm{O}]_{\mathrm{n}}\right.$ $\left.\left[\mathrm{Fe}^{\mathrm{n}+}\left(\mathrm{OH}_{2}\right)_{3}:(8-\mathrm{HQ})_{\mathrm{k}}\right]\right\}^{2-\mathrm{n}-\mathrm{k}}$ (Fig. 7):

\section{Conclusions}

The results of thermal, UV, SEM and optical images, and $\mathrm{XRD}$ studies allowed to propose the structure of the ternary composite: $\left.[>\mathrm{Si}-\mathrm{O}]_{\mathrm{n}}\left[\mathrm{Fe}(\mathrm{III})\left(\mathrm{OH}_{2}\right)_{3}(8-\mathrm{HQ})_{\mathrm{k}}\right]\right\}^{3-\mathrm{n}-\mathrm{k}}$.

This proposed structure was formed by mechanical deposition of a thin solid film of SWy-1:8-HQ on Pt and dipping the modified electrode in a $\mathrm{Fe}(\mathrm{III})$ ions aqueous solution.

In the absence of $\mathrm{Fe}(\mathrm{III})$ ions, the modified electrode showed two peaks of the CV assays, one in the anodic branch at $0 \mathrm{~V}$, and other in the cathode branch at $-0.395 \mathrm{~V}$, both with adsorptive characteristics, and low current intensity the nature of the corresponding compounds being confirmed by UV spectrophotometric data.
The electrochemical behavior of the modified Pt electrode with binary composite in the presence of $\mathrm{Fe}(\mathrm{III})$ ions in aqueous solution showed four current peaks, mutually dependent $\mathrm{A} / \mathrm{D}$ and $\mathrm{B} / \mathrm{C}$. The pair of peaks $\mathrm{A} / \mathrm{D}$ is related to the formation of a new absorptive species into the clay when $\mathrm{Fe}$ (III) ions were added to the binary aqueous suspension and can be related to the UV spectra. The second pair of peaks $\mathrm{B} / \mathrm{C}$ does not have correspondence in the UV spectra.

The following mechanism was proposed for the global electrode process:

1. CE: A/D peaks refer to the formation of the ternary complex and reduction of $\mathrm{Fe}(\mathrm{III})$ to $\mathrm{Fe}(\mathrm{II})$ species present in the complex;

2. EC: B/C peaks related to the reduction of aqueous $\mathrm{Fe}$ (III) species to aqueous $\mathrm{Fe}$ (II) ions are facilitated by the reduced form of ternary composite and oxidation of the aqueous $\mathrm{Fe}(\mathrm{II})$ species to aqueous $\mathrm{Fe}(\mathrm{III})$ by $\mathrm{O}_{2}$.

The modified electrode showed a good sensitivity to low concentrations of $\mathrm{Fe}(\mathrm{III})$ ions $\left(2.40 \pm 0.01 \mu \mathrm{mol} \mathrm{L}^{-1}\right)$ and high sensitivity to traces of $\mathrm{O}_{2}$ molecules, showing that this system has great analytical potentialities.

Acknowledgements CAPES by grant of scholarship, Laboratório de AnáliseTérmica of Departament Analytical Chemistry for the thermal study, Laboratório de Microscopia Eletrônica (LME-IQ) for the SEM facilities of Department of Chemical Physics, both of São Paulo State University (Unesp), Institute of Chemistry, Araraquara, (IQ) UNESP, Aguapé Soluções Ambientais Ltda. and Espaço Magistral Laboratório de Análises, Serviço de Apoio Empresarial Ltda., by the financial supporting for this work. X CBRATEC/ IV CPANATEC, paper 160B.

\section{References}

1. Grotto HZW. Metabolismo do ferro: uma revisão sobre os principais mecanismos envolvidos em sua homeostase. Rev Bras Hematol Hemoter. 2009;30:390-7.

2. Hoffbrand AV, Pettit FE, Moss PAH. Hypochromic anemia and iron overload in essential haematology, 5th ed, Chapter 3. Oxford: Blackwell; 2006. p. 28-43.

3. U.S. Environmental Protection Agency. Secondary drinking water regulations: guidance for nuisance chemicals. http://water. epa.gov/drink/contaminants/secondarystandards.cfm. Accessed 20 Jan 2015.

4. Ali TA, Farag AA, Mohamed GG. Potentiometric determination of iron in polluted water samples using new modified Fe(III)screen printed ion selective electrode. J Ind Eng Chem. 2014;20:2394-400.

5. Mashhadizadeh MH, Shoaei IS, Monadi N. A novel ion selective membrane potentiometric sensor for direct. Talanta. 2004;64: $1048-52$

6. Wang RY, Wu J, Wang LJ, Wang R, Dou HJ. Spectrofluorometric determination of iron II based on the fluorescence quenching of cadmium/tellurium quantum dots. Spectrosc Lett. 2014;47:439-45.

7. Junmei A, Tianrong L, Zhengyin Y, Mihui Y. An off-on fluorescent sensor with high selectivity and sensitivity for $\mathrm{Fe}(\mathrm{III})$. J Coord Chem. 2014;67:921-8. 
8. Kassem AM, Amin AS. Spectrophotometric determination of iron in environmental and food samples using solid phase extraction. Food Chem. 2013;1411:1941-6.

9. Gao X, Sun Y, Zhu G, Fan J. A green method for the determination of chromium(VI) and iron(III) in water by sequential injection analysis and spectrophotometric detection. Instrum Sci Technol. 2013;41:500-11.

10. Hassanpoor S, Khayatian G. Combination of directly suspended droplet microextraction and flame atomic absorption spectrometry for determination of trace amounts of iron and copper. J Braz Chem Soc. 2014;25:734-42.

11. Rahmana MM, Khana SB, Alamryb KA, Marwanib HM, Asiria AM. Detection of trivalent-iron based on low dimensional semiconductor metal oxide nanostructures for environmental remediation by ICP-OES technique. Ceram Int. 2014;40:8445-53.

12. Fazelirad H, Taher MA. Preconcentration of ultra-trace amounts of iron and antimony using Ion pair solid phase extraction with modified multi-walled carbon nanotubes. Microchim Acta. 2014;181:655-62.

13. Beltagi AM, Ghoneim MM. Simultaneous determination of trace aluminum(III), copper(II) and cadmium(II) in water samples by square-wave adsorptive cathodic stripping voltammetry in the presence of oxine. J Appl Electrochem. 2009;39:627-36.

14. Çiftçi H, Tamer U, Metin AÜ, Alver E, Kizir N. Electrochemical copper(II) sensor based on chitosan covered gold nanoparticles. J Appl Electrochem. 2014;44:563-71.

15. Stozhko NY, Malakhova NA, Fyodorov MV, Brainina KZ. Modified carbon-containing electrodes in stripping voltammetry of metals. Part II. Composite and microelectrodes. J Solid State Electrochem. 2008;12:1219-30.

16. Wu Z, Jiang L, Zhu Y, Xu C, Ye Y, Wang X. Synthesis of mesoporous $\mathrm{NiO}$ nanosheet and its application on mercury(II) sensor. J Solid State Electrochem. 2012;16:3171-7.

17. Promphet N, Rattanarat $P$, Rangkupanc R, Chailapakulb $O$, Rodthongkum N. An electrochemical sensor based on graphene/ polyaniline/polystyrene nanoporous fibers modified electrode for simultaneous determination of lead and cadmium. Sens Actuators B. $2015 ; 207: 526-34$.

18. Sun Y, Du H, Deng Y, Lan Y, Feng C. Preparation of polyacrylamide via surface-initiated electrochemicalmediated atom transfer radical polymerization (SI-eATRP) for $\mathrm{Pb}^{2+}$ sensing. J Solid State Electrochem. 2015. doi:10.1007/s10008-015-3008-3.

19. Maghear A, Tertis M, Fritea L, Marian IO, Indreac E, Walcarius A, Sãndulescu R. Tetrabutylammoniummodified clay film electrodes: characterization and application to the detection of metal ions. Talanta. 2014;125:36-44.

20. Filho NLD, do Carmo DR. Study of an organically modified clay: selective adsorption of heavy metal ions and voltammetric determination of mercury(II). Talanta. 2006;68:919-27.

21. Navratilova Z, Mucha M. Organo-montmorillonites as carbon paste electrode modifiers. J Solid State Electrochem. 2015;19: 2013-22.

22. Khaorapapong N, Ogawa M. Solid-state intercalation of 8-Hydroxyquinoline into $\mathrm{Li}(\mathrm{I})-, \mathrm{Zn}(\mathrm{II})-$ and $\mathrm{Mn}(\mathrm{II})$ montmorillonites. Appl Clay Sci. 2007;35:31-8.

23. Keidar O, Lapides I, Shoval S, Yariv S. Thermogravimetry and differential thermal analysis of montmorillonite treated with 1,4diaminoanthraquinone. J Therm Anal Calorim. 2015;120(1): $33-43$.

24. Souza MA, Larocca NM, Pessan LA. Highly thermal stable organoclays of ionic liquids and silane organic modifiers and effect of montmorillonite source. $\mathrm{J}$ Therm Anal Calorim. 2016. doi:10.1007/s10973-0165501-z.

25. Souza GR, Fertonani FL, Pastre IA. Estudo espectro eletroquímico de sistemas estruturados argila-corante. Eclet Quim. 2003;28:77-83.
26. Pastre IA, Nascimento OI, Moitinho ABS, Souza GR, Ionashiro EY, Fertonani FL. Thermal behaviour of intercalated 8-hydroxyquinoline (oxine) in montmorillonite clay. J Therm Anal Calorim. 2004;75:663-9.

27. Khaorapapong N, Pimchan P, Ogawa M. Formation of mixedligand zinc(II) complex-montmorillonite hybrids by solid-solid reactions. Dalton Trans. 2011;40:5964-70.

28. Pimchana P, Khaorapapong N, Sohmiyab M, Ogawa M. In itu complexation of 8 -hydroxyquinoline and $4,4^{\prime}$ bipyridine with zinc(II) in the interlayer space of montmorillonite. Appl Clay Sci. 2014;95:310-6.

29. Abollino O, Aceto M, Malandrino M, Sarzaninia C, Mentastia E. Adsorption of heavy metals on Na-montimorilonita. Effect of $\mathrm{pH}$ and organic substances. Water Res. 2003;37(7):1619-27.

30. Gök Ö, Özcan A, Erdem B, Özcan AS. Prediction of the kinetics, equilibrium and thermodynamic parameters of adsorption of copper(II) ions onto 8-hydroxy quinoline immobilized bentonite. Colloids Surf. 2008;317:174-85.

31. Juiz SA, Leles MIG, Caires ACF, Boralle N, Ionashiro M. Thermal decomposition of the magnesium zinc, lead and niobium chelates derived from 8-quinolinol. J Therm Anal Calorim. 1997;50:625-32.

32. Olewnik E, Gaman K, Czerwinki W. Thermal properties of new composites based on nanoclays, polyethylene and polypropylene. J Therm Anal Calorim. 2010;101:323-9.

33. Kissinger PI, Heineman WR. Laboratory techniques in electroanalytical chemistry. New York: Marcel Dekker; 1984.

34. Ghedini M, La Deda M, Aiello I, Grisolia A. Synthesis and photophysical characterisation of luminescent zinc complexes with 5-substituted-8-hydroxyquinolines. J Chem Soc Dalton. 2002. doi:10.1039/B202945F.

35. Silvestein RM, Bassler GC, Morrill TC. Identificação Espectrofotométrica de Compostos Orgânicos, Editora Guanabara, 3. Rio de Janeiro: Edição; 1979.

36. Bardez E, Devol I, Larrey B, Valeur B. Excited-state processes in 8-hydroxyquinoline: Photoinduced tautomerization and solvation effects. J Phys Chem B. 1997;101:7786-93.

37. Sigel H. Coordination chemistry. Oxford: Pergamon Press; 1980. p. 27-45.

38. Baes CF, Mesmer RE. The hydrolysis of cations. Library of congress cataloging in publication data, 1976.

39. Kolthoff IM, Leussing DL, Lee TS. Reaction of ferrous and ferric iron with 1, 10-phenanthroline. III. The ferrous monophenanthroline complex and the colorimetric determination of phenanthroline. J Am Chem Soc. 1950;72(5):2173-7.

40. Schilt AA. Analytical applications of 1, 10-phenanthroline and related compounds: international series of monographs in analytical chemistry. Amsterdam: Elsevier; 2013.

41. Greff R, Peat R, Peter LM, Pletcher D, Robinson J. Instrumental methods in electrochemistry. New York: Wiley/Ellis Horwood Limited; 1985.

42. Ekmekci G, Uzun D, Somer G, Kalayc1 S. A novel iron(III) selective membrane electrode based on benzo-18-crown- 6 crown ether and its applications. J Membr Sci. 2007;288:36-40.

43. Ali TA, Farag AA, Mohamed GG. Potentiometric determination of iron in polluted water samples using new modified $\mathrm{Fe}(\mathrm{III})$-screen printed ion selective electrode. J Ind Eng Chem. 2014;20:394-2400.

44. Anguiano DI, Garcia MG, Ruız C, Torres J, Alonso-Lemus I, Alvarez-Contreras L, Verde-Gómez Y, Bustos E. Electrochemical detection of iron in a Lixiviant solution of polluted soil using a modified glassy carbon electrode. Int J Electrochem. 2012. doi:10.1155/2012/739408.

45. Teixeira LSG, Brasileiro JF, Borges MM Jr, Cordeiro PWL. Determinação espectrofotométrica simultânea de cobre e ferro em álcool etílico combustível com reagentes derivados da ferroína. Quim Nova. 2006;29:741-5. 